\title{
ČEZMEJNO SODELOVANJE NA PRIMERU OBČINE TRŽIČ
}

\author{
Irena Mrak*, Slavka Zupan **
}

Izvleček

UDK 339.92(497.4 Tržič)

Občina Tržič meji z Avstrijo po grebenu Osrednjih Karavank. Povezovanje s sosednjima avstrijskima občinama (Borovlje, Sele) se je začelo v osemdesetih letih in po letu 1991 postaja $i z$ leta $v$ leto intenzivnejše. Meja, ki je nekdaj ostro ločevala življenje na obeh straneh meje, je z osamosvojitvijo Slovenije in vključitvijo Avstrije v Evropsko skupnost postala bolj odprta hkrati pa se je s Schengenskim sporazumom poostril nadzor nad pretokom blaga in ljudi. Danes gibanje ob meji ni več omejeno in nekdaj zaprta območja so postala predvsem turistično zanimiva.

$V$ teh letih je Občina Tržič z avstrijskimi partnerji izoblikovala skupne razvojne projekte, in sicer predvsem na področju razvoja kmetijstva in turizma. Tako poskusno uvajamo gojenje ajde, ki je nekdaj prevladovala na naših njivah in v vsakdanji prehrani, vključujemo pa se tudi $v$ projekt ohranjanja avtohtone pasme jezersko-solčavske ovce. Že dve leti je v program PHARE CBC (Crossborder Cooperation/Čezmejno sodelovanje) vključena tudi naravna znamenitost Dovžanova soteska, ki jo bomo v prihodnje povezali s sotesko Čepa na avstrijski strani Karavank. V okviru evropskega programa ECOS-Ouverture pa izvajamo čezmejni projekt Tematske poti po Košuti, s katerim želimo oživiti še nekoriščene pokrajinske danosti in jih vključiti v celovito turistično ponudbo na tem delu Karavank.

Ključne besede: Občina Tržič, Avstrija, čezmejno sodelovanje, Karavanke, kmetijstvo, turizem, regionalni razvoj

THE CROSSBORDER COOPERATION: A CASE STUDY OF THE TRŽIČ MUNICIPALITY

\section{Abstract}

The Municipality of Tržič borders with the Republic of Austria at the main ridge of the Karavanke mountain. Cooperation with the neighbouring communities Borovlje/Ferlach and Sele/Zell Pfare started in the eighties and it has become more intense after the year 1991.

The border that was once separating the inhabitants on both sides of the mountain ridge has become more opened after the slovenian independence but the border control is after Schengen agreement more severe. Remote mountain border areas where access used to be limited were suddenly recognised as a great touristic potential.

In the recent years the Municipality of Tržič together with Austrian partners managed to form some joined agriculture and tourism development projects within the PHARE programme

\footnotetext{
* Dipl. geog., zunanja strokovna sodelavka Občine Tržič za razvojne programe, sicer asistentka za geografijo na Filozofski fakulteti, Oddelek za geografijo

** Dipl. geog., do avgusta 1998 vodja urada za gospodarstvo Občine Tržič, sedaj projektni vodja za programe PHARE na Ministrstvu za finance, CFP
} 
(CBC - Crossborder Cooperation) and ECOS - Ouverture. The projects deal with the regrowing of buckwheat, preservation of a special sheep breed - jezersko solčavska sheep, activation of the natural monument Dovžan gorge which will be logistically connected to Tscheppa gorge on the austrian side. Within the ECOS Ouverture programme the project of Thematic trails around the Košuta mountain has been initiated in order to reactivate and connect hidden natural and cultural

potentials into integrated touristic offer of this part of the Karavanke mountain.

Key words: Municipality of Tržič, Austria, crossborder cooperation, Karavanke mountain, agriculture, tourism, regional development.

\section{UVOD}

Območje na južni in severni strani Karavank ločuje državna meja, ki tako deli sicer homogeno pokrajinsko enoto. Oba nastala dela sta se zlasti po drugi svetovni vojni razvijala ločeno drug mimo drugega, glede na usmerjenost družbeno političnega sistema, ki sta mu pripadala. Politične spremembe zadnjega desetletja so prinesle odpiranje meje in z njim se je začelo tudi čezmejno sodelovanje lokalnih skupnosti. Te so kmalu ugotovile svoje stične točke, ki kljub dolgoletni ločenosti še vedno obstajajo. Občina Tržič je tako leta 1996 začela iskati skupne razvojne priložnosti, ki jih danes lahko predstavimo z nekaterimi čezmejnimi projekti s področja kmetijstva in turizma.

\section{PREDSTAVITEV OBMOČJA}

Območje Občine Tržič in avstrijskih občin Bistrica v Rožu, Borovlje, Kotmara vas, Bilčovs, Žihpolje, Št. Jakob v Rožu, Šmarjeta v Rožu in Sele, ki so združene v turistično-razvojno regijo imenovano Carnica Region Rosental/ regija Karnija v Rožu obsega $922 \mathrm{~km} 2$.

Za območje je značilna velika pokrajinska pestrost, ki se kaže v obstoju več pokrajinskih enot. Kot osnovna med njimi izstopa pogorje Karavank, ki s svojo središčno lego pomenijo glavni pokrajinski element območja. Greben Karavank z najvišjimi vrhovi sega do nadmorske višine $2100 \mathrm{~m}$. Za slovensko stran so značilna prisojna, blaga pobočja, za avstrijsko pa osojna, pogojevana z neskladno geološko zgradbo. Gorskemu grebenu Karavank na severu in jugu sledi sredogorska pokrajina z višinami do $1500 \mathrm{~m}$, ki se počasi znižuje na jugu v uravanane fluvioglacialne terase Tržiške Bistrice, imenovane tudi Dobrave, na severu pa prav tako v fluvioglacialne terase Drave. Za celotno območje je značilna velika gozdnatost, ki znaša več kot $60 \%$. Gozd kljub stalni sečnji počasi prerašča tudi obdelovalne površine. 
Na celotnem območju živi 37.500 prebivalcev, od tega v občini Tržič 15 000, 22500 pa na ozemlju regije Karnije v Rožu, ki je dvojezično. Družbeno-gospodarske razmere na slovenski in avstrijski strani so zaradi različnega zgodovinskega razvoja dokaj različne, čeprav lahko najdemo nekaj skupnih značilnosti.

Za občino Tržič je značilna obrtno-industrijska preteklost, ki se še danes kaže v največjem deležu zaposlenih $\mathrm{v}$ sekundarnih dejavnostih. Leta 1991 je bilo $65 \%$ tržiškega aktivnega prebivalstva zaposlenega $\mathrm{v}$ industriji. Ta se $\mathrm{v}$ tem desetletju sooča s strukturnimi težavami, ki so povzročale množično odpuščanje delovne sile. Primarne dejavnosti v občini Tržič zaposlujejo majhen delež aktivnega prebivalstva $(2,8 \%)$. Kmetije v regiji Carnica v Rožu si za razliko od naših pri preživetju pomagajo z dopolnilnimi dejavnostmi, med katerimi je najpogostejši kmečki turizem. Kar 70\% kmetij je uvedlo dopolnilne dejavnosti, kar je precej nad avstrijskim povprečjem, ki znaša $59,5 \%$. V tržiški občini je le nekaj še čistih kmetij, kmetje pa si še vedno pomagajo $\mathrm{z}$ zaposlovanjem $\mathrm{v}$ tržiških industrijskih obratih, tako, da se turizem kot dopolnilna dejavnost na kmetijah le počasi uveljavlja, Občina Tržič pa spodbuja tudi druge oblike dopolnilnih dejavnosti - sirarstvo, gojenje divjadi, lesna predelava.

Turizem je na tržiškem območju slabo razvit in šele $\mathrm{v}$ zadnjem času se počasi oživljajo naravne in kulturne danosti. Regija Karnija v Rožu ima kot del Koroške turistično infrastrukturo bolje razvito, čeprav v okviru Koroške zaostaja zlasti po turističnem dohodku in išče nove možnosti, kako privabiti obiskovalce.

Glavne prednosti in priložnosti ter največje težave in ovire pri razvoju obravnavanega območja so strnjene v spodnji preglednici. 


\begin{tabular}{|c|c|}
\hline PREDNOSTI IN PRILOŽNOSTI & GLAVNI PROBLEMI IN NEVARNOSTI \\
\hline $\begin{array}{l}\text { 1. geografska lega (obmejna lega občine Tržič } \\
\text { in lega regije Carnica v Rožu v središču } \\
\text { Koroške) }\end{array}$ & 1. visoka stopnja brezposelnosti (14\%) \\
\hline 2. ohranjeno alpsko naravno okolje & 2. zmanjševanje števila čistih kmetij \\
\hline 3. velika gozdnatost & $\begin{array}{l}\text { 3. negotova prihodnost glavnih zaposlovalcev } \\
\text { industrije }\end{array}$ \\
\hline 4. kulturna in etnološka dediščina & 4. slaba infrastruktura \\
\hline 5. obrtniška znanja krajevnega prebivalstva & $\begin{array}{l}\text { 5. slabo razvita turistična ponudba in oskrbne } \\
\text { dejavnosti ter zasičenost z ustaljenimi } \\
\text { hotelsko/penzionskimi zmogljivostmi na } \\
\text { koroški strani }\end{array}$ \\
\hline $\begin{array}{l}\text { 6. sprostitev gibanja v obmejnem gorskem } \\
\text { pasu }\end{array}$ & 6. razvoj rezidenčnih /spalnih naselij \\
\hline 7. odprtje 3 novih planinskih mejnih prehodov & 7. "beg možganov" \\
\hline $\begin{array}{l}\text { 8. odprtje starega prelaza Ljubelj za potrebe } \\
\text { planinarjenja }\end{array}$ & 8. ukinjanje brezcarinskih prodajaln \\
\hline $\begin{array}{l}\text { 9. podporni programi Evropske Skupnosti } \\
\text { (IINTERREG - CROSSBORDER in drugi) }\end{array}$ & 9. zviševanje cen bencina \\
\hline $\begin{array}{l}\text { 10. pripravljenost in potreba po strokovnem } \\
\text { sodelovanju }\end{array}$ & 10. konkurenca drugih regij \\
\hline $\begin{array}{l}\text { 11. podjetniške priložnosti v kmetijstvu in } \\
\text { storitvenih dejavnostih }\end{array}$ & $\begin{array}{l}\text { 11. zmanjšanje prometa čez mejni prehod } \\
\text { Ljubelj zaradi bližine mejnega prehoda } \\
\text { Karavanke }\end{array}$ \\
\hline $\begin{array}{l}\text { 12. pozitivna demografska in razvojna politika } \\
\text { ter spodbujanje alternativnega zaposlovanja }\end{array}$ & $\begin{array}{l}\text { 12. splošna pasivnost in depresivnost tržiškega } \\
\text { prostora }\end{array}$ \\
\hline $\begin{array}{l}\text { MOŽNI REZULTAT } \\
\text { KARAVANKE - TURISTIČNO } \\
\text { REKREACIJSKO OBMOČJE, KI } \\
\text { PONUJA DOŽIVETJA BREZ MEJA }\end{array}$ & $\begin{array}{l}\text { MOŽNI REZULTAT } \\
\text { PROMETNO IN GOSPODARSKO } \\
\text { SLABO RAZVITO OBMOČJE, KI JE } \\
\text { IZGUBILO PREPOZNAVNOST } \\
\end{array}$ \\
\hline
\end{tabular}

\section{PREGLED RAZVOJA ČEZMEJNEGA SODELOVANJA}

Razvoj čezkomejnih odnosov med kraji na tržiški in boroveljsko-selski strani državne meje lahko razdelimo v tri časovno in vsebinsko povezane sklope:

- gospodarsko sodelovanje med prebivalci na obeh straneh Karavank, vezano na promet čez gorski prelaz Ljubelj in trgovanje med Kranjsko in Koroško, 
- formalno sodelovanje po drugi svetovni vojni in obdobje motorizirnega prometa skozi ljubeljski predor,

- čas iskanja novih spodbud in vzpostavljanje partnerskih odnosov, ki temeljijo na obojestranskih koristih gospodarskega sodelovanja in sonaravnega razvoja skupnega prostora - Karavank.

1. Gospodarsko sodelovanje med prebivalci na obeh straneh Karavank, vezano na promet čez zahtevni gorski prelaz Ljubelj in trgovanje med Kranjsko in Koroško deželo do leta 1920

Prometna pot čez gorski prelaz Ljubelj, ki je že v rimskih časih povezovala Emono in Virunum na Gosposvetskem polju, je vplivala na razvoj poselitve, obrtništva in s tranzitom povezanih dejavnosti v dolinah na obeh straneh tega dela Karavank.

Trgovanje in promet čez Ljubelj sta še posebej narasla, ko je leta 1382 Trst pripadel Avstriji. Ob zahtevni in za konjsko vprego naporni poti čez gorski prelaz Ljubelj so se na obeh straneh razvile "podporne" dejavnosti: furmani, hospici - zavetišča, gostišča s prenočišči, pošta, popravljalnice vozov, vzdrževalci ceste, mitničarji, čuvajnice, prekladalnice blaga .... . Čez Ljubelj pa so trgovali in med seboj bili konkurenčni boj tržiški in koroški obrtniki vse do pojava železnice.

Prva izgubljena priložnost za Tržič in Borovlje je bila zavrnitev izgradnje železniškega predora pod ljubeljskim prelazom, kot je to načrtoval že Valvasor, in odprtje gorenjske železniške proge, ki je leta 1870 ves tovorni promet s Koroške preusmerila čez Trbiž v Ljubljano.

Kazalo je, da z vzpostavitvijo državne meje na Karavankah leta 1920 načrtov o ljubeljskem predoru ne bo več možno uresničiti. Kraji in storitvene dejavnosti ob cesti so za nekaj desetletij izgubili dohodke od tranzitnega prometa.

\section{Formalno sodelovanje po drugi svetovni vojni in obdobje motoriziranega prometa skozi ljubeljski predor}

Z nastankom jugoslovanske države in vzpostavitvijo državne meje so Karavanke, nekdaj zgolj naravna ovira, postale še politična pregrada, zlasti $\mathrm{v}$ očeh prebivalcev avstrijske Koroške, ki se niso strinjali z drugačno politično ureditvijo na jugu in so jo prilično zavračali.

Kljub temu je ideja o predoru ostala, uresničevati pa se je začela z nacističnimi načrti izgradnje Jadranske ceste. Med drugo svetovno vojno sta tako obe ljubeljski dolini postali tragično gradbišče, kjer so taboriščniki podružnic Mauthausna na obeh straneh gradili predor in ga leta 1944 tudi prebili. Vendar pa je promet še vse do leta 1963 potekal čez stari prelaz Ljubelj, ker

do predora ni bila zgrajena priključna cesta, nova država pa se z Avstrijo do leta 1961 ni sporazumela glede dograditve in obratovanja predora.

Razmah motornega tranzitnega prometa skozi ljubeljski predor proti Jadranu je $\mathrm{v}$ sedemdesetih letih v Podljubeljski dolini spodbudil gradnjo novih turističnih objektov 
(menjalnica, hotel, restavracije, kasneje tudi brezcarinske prodajalne...). Trgovini na avstrijski strani pa so pomembne dohodke, poleg tranzitnih, prinašali tudi slovenski potrošniki.

Če je motorni promet po magistralni cesti skozi ljubeljski predor potekal kolikor toliko nemoteno vse do odprtja predora Karavanke $v$ devetdesetih letih, pa je bila zelena meja na pobočjih Karavank strogo nadzorovana, prosto gibanje $\mathrm{v}$ t.i. obmejnem pasu pa omejeno.

Tudi uradno sodelovanje med sosednjimi občinami Tržič, Borovlje in Sele je bilo v tem obdobju skromno in zelo uradno, tesnejše vezi so nastajale le med posameznimi prostovoljnimi organizacijami, predvsem gasilci in nekaterimi slovenskimi kulturnimi društvi.

\section{3. Čas iskanja novih pobud in vzpostavljanje partnerskih odnosov, ki temeljijo na obojestranskih koristi gospodarskega sodelovanja in sonaravnega razvoja skupnega prostora Karavank}

Preusmeritev tovornega prometa in glavnih tranzitnih tokov ljubeljskega prehoda na predor Karavanke in krizne razmere na Balkanu so $\mathrm{v}$ začetku devetdesetih let, ponovno ogrozile in osamile obmejni prostor Karavank.

Struktura gospodarskih dejavnosti se je začela preusmerjati in prilagajati enodnevnim obiskovalcem in regionalnemu prometu med Ljubljano in Celovcem. Krizne razmere so prisilile domačine $\mathrm{k}$ iskanju različnih rešitev. Tako je bila $\mathrm{v}$ začetku devetdesetih let v Tržiču zelo živa ideja o vzpostavitvi brezcarinskega območja v vsej Podljubeljski dolini po vzoru nekaterih drugih alpskih dolin. Tudi to je pripomoglo, da so stiki med sosednjimi občinami postajali vse bolj konkretni.

Za sedanji razvoj čezmejnih dejavnosti sta posebnega pomena tudi dva dokumenta in sicer:

- $\quad$ izjava o namenu ponovne oživitve stare ljubeljske ceste v skupno korist, kar bi poživilo celotno s tem povezano obmejno regijo na obeh straneh državne meje, ki so jo na starem Ljubelju 20.4.1990 podpisali župani Borovelj, Sel in Tržiča,

- $\quad$ listina o pobratenju, ki so jo leta 1994 sprejeli organi občin Borovlje in Tržič.

Pobratenje naj bi spodbudilo pogostejše stike občinskih uprav, ustanov in društev, predvsem pa odprlo tudi pot poslovnemu sodelovanju med malimi podjetniki. Kmalu se je pokazalo, da je uresničenje poslovnih odnosov odvisno od potreb dveh gospodarskih družb, zato je sodelovanje vse do leta 1996 obstalo le pri kulturni in športni izmenjavi.

Dodaten vzvod k novim čezmejnim dejavnostim je bila večmesečna delna zapora ljubeljskega predora pozimi 1996/97, ki je še enkrat pokazala na veliko odvisnost 
tržiške ponudbe (predvsem gostinskega sektorja) od prometa čez Ljubelj. Po drugi strani pa postaja odvisnost od enodnevnih obiskovalcev, ki tako na eno kot na drugo stran vse poredkeje prihajajo zaradi gospodarskih razlogov (cenejši bencin, frizerske, gostinske in druge storitve), s približevanjem Slovenije Evropski skupnosti vse bolj tvegana.

\section{PREDSTAVITEV SEDANJIH PROJEKTOV}

\section{Okoliščine in izhodišča za oblikovanje čezmejnih razvojnih projektov}

Opisani razlogi so bili povod, da je tudi Občina Tržič preko programa PHARE/CBC $(\mathrm{CBC}=$ Crossborder Cooperation, slovensko program čezmejnega sodelovanja, $\mathrm{v}$ nadaljevanju PHARE/CBC) kandidirala za pridobitev finančnih sredstev, namenjenih razvoju obmejnih regij ter se pri tem povezovala s sosednjima občinama Jesenice in Preddvor (sedaj Jezersko). Med desetimi predlogi je uspela pridobiti financiranje za pet projektov in sicer:

- Naravni spomenik Dovžanova soteska (varstvo in predstavitev naravne dediščine)

- Karavanke - doživetja brez meja (razvoj nove turistične ponudbe),

- Restavratorska šola (ustanovitev prve srednje šole v Tržiču ),

- Ponovno uvajanje ajde (razvoj novih kmetijskih izdelkov in dopolnilnih dejavnosti na kmetijah),

- Jezersko-solčavska ovca (Občina Tržič je skupaj s tržiškimi rejci te pasme ovac vključena v projekt kot partner).

Čezmejni značaj ima tudi projekt "Tematske poti po Košuti”, ki ga sofinancira Evropska skupnost v okviru programa ECOS-Ouverture.

\subsection{Projekt: NARAVNI SPOMENIK DOVŽANOVA SOTESKA}

Področje: $\quad$ varovanje naravne dediščine, turizem.

Območje: $\quad$ naravni spomenik Dovžanova soteska leži nekaj kilometrov severno od Tržiča, zavarovano območje obsega 180 ha.

Nosilec: Občina Tržič

Viri financiranja: $\quad$ PHARE/CBC, Ministrstvo za okolje in prostor, Občina Tržič.

Vrednost projekta: $\quad 350.000$ EUR.

\section{Izhodišča:}


Naravni spomenik Dovžanova soteska je bil z občinskim odlokom zavarovan leta 1988. Razlog za zavarovanje je bilo edinstveno nahajališče karbonskih in permskih fosilnih vrst, soteska kot geomorfološki pojav ter posebne vegetacijske združbe, značilne le za to območje. Potreba po urejanju soteske se je pokazala zaradi vse večjega zanimanja za obisk te naravne znamenitosti, občina pa je s pospeševanjem turizma v Dovžanovi soteski zaslutila veliko priložnost. Leta 1994 je bil izdelan in sprejet Ureditveni načrt in s pomočjo občinskih in republiških sredstev se je začelo urejanje.

\section{Cilji:}

- dokončna ureditev naravne znamenitosti: dokončanje turističnih oglednih poti in njihova označitev, razstavno-izobraževalnega središča v stari šoli v vasi Dolina,

- $\quad$ ureditev oskrbe $z$ vodo na šišem območju Dovžanove soteske,

- vključevanje krajevnega prebivalstva pri oblikovanju turistične ponudbe območja,

- $\quad$ povečevanje števila obiskovalcev, ne da bi to škodilo naravni znamenitosti.

\section{Dejavnosti:}

Občina Tržič je v okviru programa PHARE/CBC pridobila sredstva za izdelavo turistične ogledne poti skozi najožji del soteske v skladu ureditvenim načrtom. Pogoj za pridobitev sredstev je bil izdelan projekt, s katerim je soglašal Zavod za varovanje naravne in kulturne dediščine iz Kranja. Pot bo predvidoma dokončana konec leta 1999.

Iz istega vira je del sredstev namenjenih izgradnji vodovoda za prebivalce vasi Dolina in Jelendol, ki še nimata urejenega javnega vodovoda. V sklopu naravnega spomenika Dovžanova soteska je predvidena tudi obnova stare šole v vasi Dolina nad Dovžanovo sotesko, ki bo služila kot razstavno-izobraževalno središče soteske. Del sredstev je ES namenila tudi za obnovo te zgradbe, ki bo smiselno zaokrožila delovanje naravnega spomenika Dovžanove soteske.

Le nekaj deset kilometrov proti severu je na avstrijski strani znana soteska Čepa, ki sicer ni poznana kot svetovna geološka dediščina, je pa vsekakor zanimiv geomorfološki in botanični pojav, ki ga vsako leto obišče desetkrat več obiskovalcev kot Dovžanovo sotesko (5000 obiskovalcev na leto v Dovžanovi soteski in $55000 \mathrm{v}$ soteski Čepa). Ti prinesejo krajevnim oblastem kar 2 milijona ATS. V sodelovanju s koroško deželno vlado smo se dogovorili za skupno predstavitvijo obeh sotesk ter za pomoč in prenos znanja avstrijskih strokovnjakov pri trženju Dovžanove soteske. 


\subsection{KARAVANKE - "DOŽIVETJA BREZ MEJA"}

Področje:
Območje:

Nosilec:

ES - partner:

Ostali partnerji:

Viri financiranja:

Vrednost projekta: turizem, podjetništvo.

občina Tržič, Jesenice ter občine regije Karnija v Rožu.

Občina Tržič, Urad za gospodarstvo.

Carnica Region Rosental/Rož, Avstrija.

zasebna turistična podjetja .

PHARE/CBC, lastna sredstva vključenih podjetnikov, občina Tržič.

8.000 EUR.

Opis:

Upadanje števila enodnevnih in tranzitnih gostov zahteva takojšnje oblikovanje in trženje nove turistične ponudbe.

Zaradi potreb turističnega gospodarstva tako na avstrijski, še zlasti pa na tržiški strani smo v letu 1998 izvedli dva pilotna projekta. Pod geslom "Karavanke - doživetja brez meja" smo skupaj s tržiškim in avstrijskim podjetnikom oblikovali devet poletnih in šest zimskih turističnih programov. V obeh primerih je bil izdelan dvojezični prospekt in vzpostavljen informacijski sistem preko informacijskih središč v Tržiču in Borovljah.

Osnovna izhodišča pri oblikovanju programov so:

- aktivno doživljanje doslej nepoznanega obmejnega gorskega sveta (pohodništvo,gorsko kolesarjenje, turno smučanje, sankanje, hoja s krpljami, baklami, vožnja s kanuji...),

- inovativnost,

- usmerjenost na ciljne skupine: družine z otroki, ki imajo rade naravo; zaključene skupine in aktivne skupine mladih;

vključevanje različnih ponudnikov turističnih storitev.

Poletni turistični program smo prvič tržili v sezoni maj-oktober 1998. Rezultati so bili slabši od pričakovanih, saj je bilo prodanih le nekaj enodnevnih programov (najuspešnejši je izlet na Stari Ljubelj). Vzroki zanje so predvsem v prepoznem in premalo strokovnem pristopu $\mathrm{k}$ trženju ter prezahtevnih oz. preveč specializiranih programih za obiskovalce.

Kljub temu pa je prvi pilotni projekt pritegnil pozornost medijev in krajevnega prebivalstva na obeh straneh meje, še zlasti pa so se $\mathrm{v}$ tem času izoblikovali medsebojni odnosi v mešani projektni skupini, načini komuniciranja in dela.

Izkušnje iz poletnega pilotnega projekta so se že upoštevale pri pripravi zimskih programov, njegovi rezultati pa bodo odločilni pri odločitvah o širjenju pilotnih projektov. 


\subsection{RESTAVRATORSKA ŠOLA}

Področje:

Območje:

Nosilec:

EU partner:

Ostali partnerji:

Viri financiranja:

Vrednost projekta: razvoj človeških virov, srednje šolstvo.

občina Tržič $\mathrm{V}$ povezavi $\mathrm{Z}$ gorenjskimi in avstrijskokoroškimi poklicnimi strokovnimi šolami.

Občina Tržič.

Občina Borovlje, Avstrija.

Restavratorski center, Ministrstvo za šolstvo in šport, PHARE CBC, Občina Tržič, 54.000 EUR (1.stopnja).

Izhodišča:

Pobuda za vzpostavitev restavratorske srednje šole v Tržiču temelji na treh dejstvih:

- $\quad$ izobrazbena struktura tržiškega prebivalstva je pod slovenskih povprečjem,

- Tržič nima srednje šole,

- obrtniška tradicija in raznovrstna obrtna znanja.

\section{Cilji:}

Strateški cilj je izboljšanje ponudbe srednješolskih programov, zapolnitev vrzeli $\mathrm{V}$ restavratorskem poklicnem izobraževanju, pritegniti novo kvalitetno dejavnost $\mathrm{v}$ tržiško mestno jedro, izboljšati poklicne možnosti in dostopnost srednješolskega programa lokalnemu prebivalstvu.

\section{Dejavnosti:}

Izvedba projekta je odvisna od rezultatov začetnega obdobja, ki go sofinancira Evropska skupnost in bo potekal v letu 1999. Začetno obdobje predvideva naslednje rezultate:

- analizo potreb po specializaciji $\mathrm{v}$ restavratorstvu ter analizo ponudbe restavratorskih srednjih šol v srednjeevropskem prostoru,

- predlog restavratorskih smeri in zasnova učnega programa,

- $\quad$ poslovni načrt za delovanje šole z različnimi predlogi za ustanovitev šole. 


\title{
4.4. PONOVNO UVAJANJE AJDE
}

\author{
Področje: $\quad$ kmetijstvo. \\ Območje: $\quad$ občina Tržič in Naklo. \\ Nosilec: Občina Tržič. \\ Viri financiranja: Občina Tržič, PHARE CBC. \\ Vrednost projekta: $\quad 5.000$ ECU.
}

\section{Izhodišča:}

Ajda je bila eden pomembnejših pridelkov hribovitih predelov Slovenije v preteklih stoletjih. Po letu 1960 so jo začeli nadomeščati koruza in drugi posevki. V zadnjih letih se je povpraševanje po ajdi ponovno povečalo.

Ideja o ponovnem uvajanju ajde na tržiška polja se je porodila v letu 1995 , ko je Občina Tržič v sodelovanju z Univerzo v Ljubljani pričela s sejanji poskusnih sort ajde. Idejo so podprli tudi kmetje.

\section{Cilji:}

- določitev ustrezne sorte, ki najbolje uspeva v našem podnebju in ki ji ustrezajo talne razmere,

- razširitev območja gojenja ajde v letu 1998 in ob koncu, v decembru, organizacija delavnice, s katero bodo predstavljene jedi iz ajde,

- prenos znanja in izkušenj na avstrijske partnerje, ki imajo $\mathrm{z}$ gojenjem ajde $\mathrm{v}$ zadnjem času manjše izkušnje, čeprav je bila ajda tudi pri njih v preteklosti pomemben pridelek.

Zastavljeni cilji so bili v večji meri doseženi, v sodelovanju z Biotehniško fakulteto nam je uspelo določiti najboljšo sorto ajde, ki uspeva na tem območju. Kmetje so za gojenje te rastline vse bolj zainteresirani, zato se bo projekt $\mathrm{v}$ prihodnosti nadaljeval in razširil tudi na uvajanje čebelje paše na ajdovih poljih ter uporabe nadzemnih delov rastline za izdelavo posebnih blazin.

\subsection{Projekt: OŽIVITEV REJE AVTOHTONE JEZERSKO-SOLČAVSKE PASME OVAC}

Področje:

Območje:

Nosilec:

Viri financiranja: kmetijstvo.

občine Tržič, Jezersko, Preddvor, Solčava.

Društvo rejcev ovac jezersko-solčavske pasme Jezersko.

PHARE CBC, lastna sredstva vključenih rejcev, sredstva vključenih občin. 


\section{Izhodišča:}

Jezersko-solčavska pasma ovac je avtohtona pasma v osrednjem delu Karavank (Tržič, Jezersko) in na Solčavskem. Reja te pasme se je med slovenskimi visokogorskimi kmeti bolj ohranila kot na sosednji koroški strani, zato so se Avstrijci pridružili k projektu spodbujanja reje jezersko-solčavske pasme na njihovi strani. Leta 1997 je bilo na Jezerskem ustanovljeno Društvo rejcev ovac jezersko-solčavske pasme in takrat je bil podoben projekt zasnovan tudi na naši strani.

Cilji:

- povečanje staleža živali,

- povečanje števila rejcev,

- ohranjanje kulturne krajine (ohranitev visokogorskih travnikov in planin),

- usklajeno čezmejno vodenje redovniške knjige,

- $\quad$ napredek v selekciji živali (selekcijsko središče),

- izmenjava izkušenj in sodelovanje čez mejo,

- izmenjava plemenskih živali in genskega materiala,

- $\quad$ skupni nastop pri reklami in ponudbi na celotnem območju avtohtone pasme,

- dodatna popestritev turistične ponudbe,

- $\quad$ skupna zaščitena blagovna znamka za vse izdelke iz te dejavnosti,

- $\quad$ oprema za prodajo izdelkov v specializirani trgovini,

- osveščenost ponudnikov (tako rejcev, gostincev, trgovcev kot ostalih turističnih delavcev),

\section{Dejavnosti:}

- $\quad$ obveščanje potrošnikov o posebnosti izdelkov, značilnih za to ovco in območje.,

- popularizacija ovce (aktivno nastopanje in predstavitev na razstavah, sejmih in $\mathrm{v}$ medijih s predstavitvenim gradivom),

- nadzor nad zdravstvenim stanjem ter razmnoževanjem tropov,

- priključitev na spletno omrežje zaradi izmenjav podatkov iz rodovniške knjige med slovenskimi in avstrijskimi rejci ter Biotehniško fakulteto in zbornico,

- $\quad$ organizacija turističnih prireditev in razstav v sodelovanju z avstrijskimi rejci,

- oblikovanje lastne blagovne znamke,

- strokovna predavanja in izobraževanja za rejce, trgovce in turistične delavce,

- $\quad$ strokovna pomoč pri organizirani visokogorski paši. 


\subsection{TEMATSKE POTI PO KOŠUTI}

Področje: $\quad$ regionalni razvoj, turizem, razvoj podeželja, naravna in

Območje:

Nosilec:

EU partner:

Občina Tržič kulturna dediščina.

Viri financiranja: PHARE ECOS-OUVERTURE.

Vrednost projekta: 49.000 EUR.

\section{Cilji:}

- vzpostaviti prepoznavno čezmejno turistično rekreativno območje $\mathrm{v}$ delu Karavank (Ljubelj-Košuta), ki bo temeljilo na aktivnem in "brezmejnem" doživljanju narave,

- povečati sposobnost preživetja malega krajevnega turističnega gospodarstva,

- dvigniti konkurenčnost turistične ponudbe z razvojem novih izdelkov,

- $\quad$ omogočiti nove priložnosti za delovna mesta $v$ obmejnem podeželskem prostoru: podjetništvo, dodatne storitvene in kmetijske dopolnilne dejavnosti,

- začeti s skupnim trženjem območja.

\section{Dejavnosti:}

V obdobju enega leta, kolikor traja projekt (do marca 2000), so bile in bodo izvedene naslednje dejavnosti:

- izdelava načrta tematskih poti na podlagi naravnih, kulturnih, podjetniških in človeških možnosti ter ob upoštevanju ciljnih skupin uporabnikov tematskih poti območju občine Tržič,

- $\quad$ izdelava povezav z mrežo tematskih poti na avstrijski strani,

- usposabljanje slovenske podjetniške skupine in vključevanje ponudnikov storitev ob tematskih poteh,

- izdelava načina trženja turističnega izdelka "mreže čezmejnih tematskih poti",

- vzpostavitev informacijsko-predstavitvenega središča centra za nadaljnje uresničevanje projekta,

- določitev in opis treh tematskih poti s spremljevalnimi brošurami ter vzpostavitev ene poti s popolno opremo. 


\section{SKLEPI}

Tržiške izkušnje pri čezmejnem sodelovanju so pokazale, da mora le to temeljiti na skupnih željah in potrebah in ne na podlagi najrazličnejših uradnih sporazumov in listin. Čezmejno sodelovanje je postopen proces, sodelovanje pa se sproti oblikuje, dopolnjuje, usmerja in širi. Partnerstvo je možno le na podlagi enakovrednosti in enakopravnosti sodelujočih partnerjev, pri čemer osebnostne lastnosti posameznikov niso zanemarljive.

Kakor se razvija čezmejno medobčinsko sodelovanje, tako se postopoma razvijajo tudi novi skupni projekti. Rezultatov ne gre pričakovati takoj, potreben je čas za zorenje in preverjanje idej, kakor tudi večkratni poskusi, ki vedno ne prinesejo uspeha.

Pravi čezmejni projekti so rezultat dejanskih potreb določenega prostora, ki jih morajo podpirati zainteresirani podjetniki, kmetje, odgovorni strokovnjaki in predvsem tudi politiki.

Pregled aktualnih čezmejnih projektov v obdobju 1995-1998 v občini Tržič sicer dokazuje, da so bili ključni povod za njihovo oblikovanje finančne spodbude, ki jih za tovrstne regionalno razvojne projekte namenja Evropska skupnost, ob tem pa so ključnega pomena tudi nosilci projektov in ljudje v njih sodelujejo.

\section{LITERATURA IN VIRI:}

1. Kragl V., 1936: Zgodovinski drobci Župnije Tržič, 1936.

2. Mohorič I., 1965: Zgodovina industrije, gozdarstva in obrti v Tržiču, 1965.

3. Projektna dokumentacija Občine Tržič med leti 1995-1998.

4. Gospodarska in zaposlitvena gibanja v občini Tržič. Občina Tržič, Urad za gospodarstvo, 1998. 


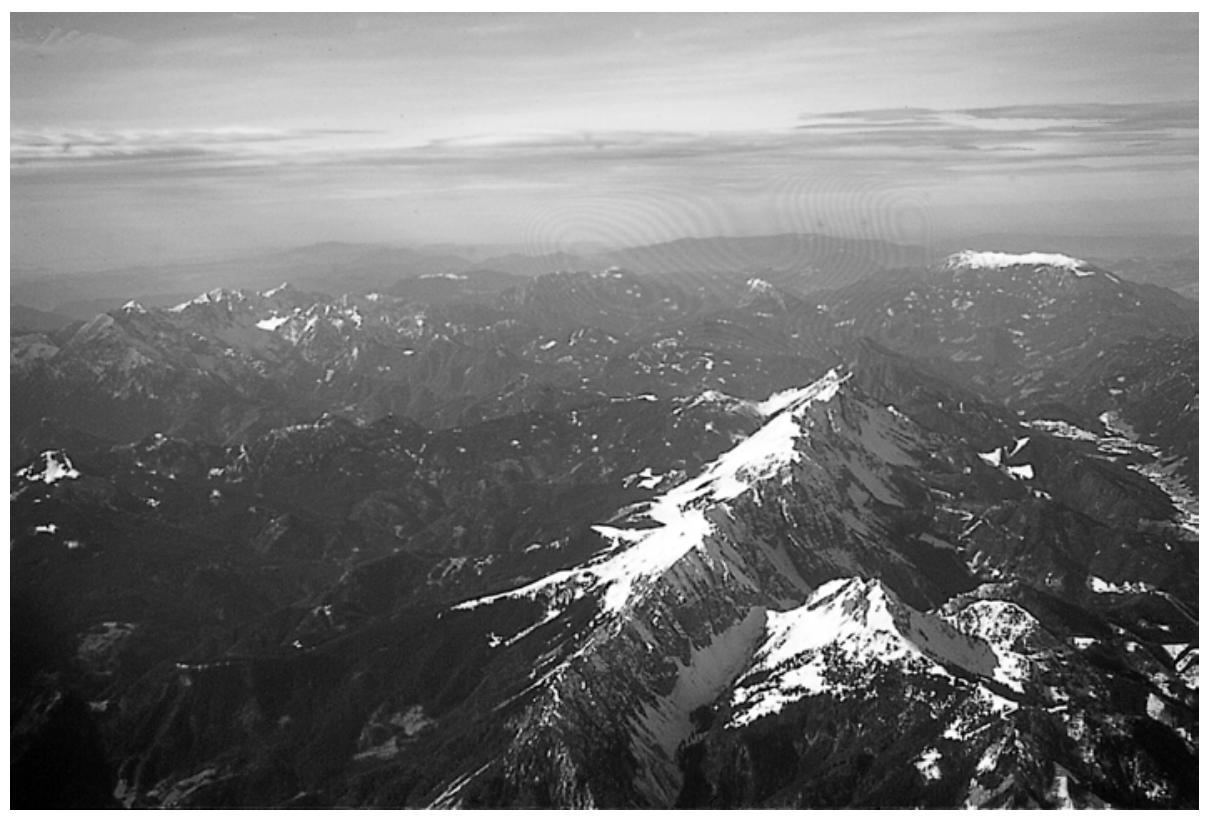

